\title{
The Effect of Dipyridamole on the Coronary Hemodynamics in Man
}

\author{
Kohji Tamura, M.D., Teizi Honda, M.D., Norio Muto, M.D., \\ and Shozo BannaI, M.D.
}

\section{SUMMARY}

The effects of Dipyridamole (Persantin) on the coronary blood flow (the great cardiac vein flow and coronary sinus ostial flow), the femoral arterial pressure, the coronary vascular resistance and the heart rate were measured continuously in man.

The newly devised method of the continuous local thermodilution method enabled us to perform the exact measurement of the above mentioned variables in man.

The increase of the coronary blood flow was seen definitely in the non-ischemic group and, therefore, the decrease in the coronary vascular resistance occurred in $30 \mathrm{sec}$ and continued for more than $20 \mathrm{~min}$. In the myocardial ischemic group, some patients showed the similar response to the non-ischemic group. However, some patients showed no increase of the flow, even though the coronary vascular resistance decreased in all cases in this group. The heart rate increased slightly in all cases.

\section{Additional Indexing Words:}

Dipyridamole Coronary blood flow

\begin{abstract}
7 HE data that Dipyridamole increases the coronary blood flow in the 1 animals have been reproducible and well accepted. ${ }^{1,2)}$ However, because of the technical difficultics in the clinical medicine, the direct proof in man that Dipyridamole increases the coronary blood flow and decreases the coronary vascular resistance is poor and incomplete. ${ }^{3)-111}$

Since we developed the new method for the continuous measurement of the coronary sinus blood flow in $\operatorname{man}_{2}{ }^{12}$ ) an attempt to prove the increase of the coronary blood flow by Dipyridamole in man became possible. Therefore, the object of this study was to examine the changes of the coronary blood flow and the coronary vascular resistance in man after Dipyridamole continuously using this newly developed local thermodilution method.
\end{abstract} Japan.

From the First Department of Medicine, Niigata University School of Medicine, Niigata City 951 ,

Received for publication September 13, 1974. 


\section{Material AND Method}

The 14 patients under the usual cardiac catheterization studies were selected randomly for this clinical experiment (Table I). This study was performed immediately after the usual catheterization. The patients were classified into 2 groups, namely (A) the myocardial non-ischemic group as the control and (B) the myocardial ischemic group. The criteria of the myocardial ischemia were the followings: (1) the inpatients due to the acute myocardial infarction with the definite electrocardiographic and enzymatic changes, (2) the patients of angina pectoris in whom the spontaneous attacks showed the transient and reversible horizontal depression of the ST segment in the electrocardiogram and the attacks were relieved by nitroglycerin. The patients without the myocardial ischemia criteria were classified as the myocardial non-ischemic group. In order to correlate the reaction of the coronary blood flow to Dipyridamole, with each patient, the clinical manifestations and the laboratory findings of each patient were summarized in Table I.

The patients were premedicated by morphine $\mathrm{HCl}(10 \mathrm{mg})$ and phenobarbital (20 mg) intramuscularly.

The simultaneous measurements of the flow in the great cardiac vein and the coronary sinus were performed by the newly developed method of the continuous local thermodilution method. ${ }^{12}$ A specially designed catheter (equivalent 7F) (Wilton Webster Manufacturing Company, USA) was inserted into the coronary sinus. This catheter has the injection orifice at the top of it and the 3 thermistors. The 2 external thermistors were mounted outside of the catheter, namely $10 \mathrm{~mm}$ (great cardiac vein) and $30 \mathrm{~mm}$ (coronary sinus) and the 1 thermistor was mounted inside the catheter to measure the termperature of the indicator. The temperature was measured with the thermistors incorporated in one arm of a Wheatstone bridge, the signal was amplified and recorded by the photorecorder (Yokogawa, Type 2902) continuously. The $5 \%$ glucose solution was infused continuously by a specially designed infusion pump through the small hole at the tip of the catheter into the great cardiac vein for the mixing. The temperature of the blood, the mixture of the blood, and the indicator were measured by the external thermistors. The flows were converted from the changes of the temperature of the mixture of the blood and the indicator according to the formula that was already reported. ${ }^{12)}$

After $30 \mathrm{sec}$ of the infusion of the indicator, the flow became stable and Dipyridamole $(10 \mathrm{mg}$ ) was injected intravenously in a single shot. The changes of the flow after Dipyridamole were recorded continuously.

The Seldinger needle of G17 was inserted into the femoral artery to record the changes of the mean arterial pressure. The coronary vascular resistance was calculated by the mean arterial pressure divided by either the great cardiac vein flow or the coronary sinus ostial now. Moreover, the morphologies and the rhythm changes in the electrocardiogram were also analysed during the procedure.

\section{RESUlts}

The data of the effects of Dipyridamole on the coronary hemodynamics 
Table I. The Clinical Manifestations and the Laboratory Findings of the Patients Examined in This Study

A. Myocardial Non-Ischemic Group

\begin{tabular}{|c|c|c|c|c|c|c|c|c|}
\hline \multirow{2}{*}{$\begin{array}{l}\text { Case } \\
\text { No. }\end{array}$} & \multirow{2}{*}{$\underset{\text { Age }}{\text { Name \& }}$} & \multirow[b]{2}{*}{ Sex } & \multirow{2}{*}{$\begin{array}{l}\text { Body } \\
\text { Sur- } \\
\text { face } \\
\left(\mathrm{M}^{2}\right)\end{array}$} & \multirow{2}{*}{\multicolumn{2}{|c|}{ Clinical Diagnosis }} & \multirow{2}{*}{$\begin{array}{l}\text { BP } \\
\text { mmHg }\end{array}$} & \multicolumn{2}{|c|}{ ECG Findings } \\
\hline & & & & & & & \multicolumn{2}{|c|}{ At Rest } \\
\hline 1 & K. O. 55 & $\mathbf{M}$ & 1.56 & \multicolumn{2}{|c|}{ Aortic insufficiency } & $\begin{array}{l}\mathrm{SV}_{1} \\
\mathrm{~L}_{\mathbf{1}, 2}\end{array}$ & \multicolumn{2}{|c|}{$\begin{array}{l}\mathrm{SV}_{1}+\mathrm{RV}_{5}=40 \mathrm{~mm} \\
\mathrm{~L}_{1,2}, \mathrm{~V}_{4,5,8} \mathrm{ST} \text { depression }\end{array}$} \\
\hline 2 & S. S. 30 & $M$ & 1.60 & \multicolumn{2}{|c|}{$\begin{array}{l}\text { Aortic insufficiency, Chronic } \\
\text { glomerulonephritis }\end{array}$} & $180 / 30 / 0$ & \multicolumn{2}{|c|}{$\begin{array}{l}S V_{\mathrm{L}}+\mathrm{RV} V_{\mathrm{b}}=70 \mathrm{~mm} \\
\text { No } \mathrm{ST} \text { depression }\end{array}$} \\
\hline 3 & S. A. 33 & $M$ & 1.71 & \multicolumn{2}{|c|}{ Innocent murmur } & $\begin{array}{l}\text { Nor } \\
\text { (SV }\end{array}$ & \multicolumn{2}{|c|}{$\begin{array}{l}\text { Normal } \\
\left(\mathrm{SV}_{1}+\mathrm{RV}_{5}=28 \mathrm{~mm}\right)\end{array}$} \\
\hline 4 & M. S. 21 & $\mathbf{M}$ & 1.72 & \multicolumn{2}{|c|}{ Myocardiopathy } & $\begin{array}{l}\mathrm{SV} \\
\mathrm{STV} \\
\mathrm{STV} \\
\mathrm{TV}\end{array}$ & \multicolumn{2}{|c|}{$\begin{array}{l}\mathrm{SV}_{\mathrm{L}}+\mathrm{RV}_{5}=45 \mathrm{~mm} \\
\mathrm{STV}_{5,6}: \text { depressed } \\
\mathrm{STV}_{1,2}: \text { elevated } \\
\mathrm{TV}_{4-6}: \text { negative }\end{array}$} \\
\hline 5 & A. K. 50 & $\mathrm{~F}$ & 1.30 & \multicolumn{2}{|c|}{$\begin{array}{l}\text { Thromboembolism of both } \\
\text { ext. iliac Vs. }\end{array}$} & $112 / 60$ & \multicolumn{2}{|c|}{$\mathrm{SV}_{\mathrm{L}}+\mathrm{RV}_{\mathrm{s}}=41 \mathrm{~mm}$} \\
\hline 6 & K. E. 52 & $\mathbf{M}$ & 1.62 & \multicolumn{2}{|l|}{ Mitral stenosis } & $140 / 88$ & \multicolumn{2}{|c|}{ Atrial fibrillation, iRBBB } \\
\hline 7 & I. S. 28 & $\mathrm{~F}$ & 1.38 & \multicolumn{2}{|c|}{ Aortitis syndrome } & $154 / 48$ & \multicolumn{2}{|c|}{ Normal } \\
\hline 8 & Y. S. 23 & $\mathrm{~F}$ & 1.40 & \multicolumn{2}{|l|}{ Mitral stenosis } & $108 / 70$ & \multicolumn{2}{|c|}{ RVH, Mitral $P$} \\
\hline 9 & M. K. 39 & $\mathbf{M}$ & 1.62 & \multicolumn{2}{|c|}{ Mitral stenosis (restenosis) } & $\begin{array}{l}\text { Atri } \\
\text { LVI }\end{array}$ & \multicolumn{2}{|c|}{$\begin{array}{l}\text { Atrial fibrillation, RVH, } \\
\mathrm{LVH}\end{array}$} \\
\hline \multirow[b]{2}{*}{$\begin{array}{l}\text { Case } \\
\text { No. }\end{array}$} & \multirow[b]{2}{*}{$\underset{\text { Age }}{\text { Name \& }}$} & \multirow[b]{2}{*}{ Sex } & \multirow{2}{*}{$\begin{array}{l}\text { Body } \\
\text { Sur- } \\
\text { face } \\
\left(\mathrm{M}^{2}\right)\end{array}$} & \multirow{2}{*}{\multicolumn{2}{|c|}{\begin{tabular}{|c|c|} 
ECG Findings & Ghest X-ray \\
Film Cardio- \\
Master's Test & $\begin{array}{c}\text { thoracic } \\
\text { Ratio }\end{array}$ \\
\end{tabular}}} & \multirow{2}{*}{$\begin{array}{l}\text { PCG } \\
\text { Findings }\end{array}$} & \multicolumn{2}{|c|}{ Cardiac Catheterization } \\
\hline & & & & & & & $\begin{array}{c}\text { PA Wedge } \\
\text { Pressure }\end{array}$ & $\begin{array}{l}\text { RV Diastol- } \\
\text { ic Pressure } \\
\text { (rnm Hg) }\end{array}$ \\
\hline 1 & K. O. 55 & $M$ & 1.56 & - & 50.0 & 4LSB, DM & 6.0 & 5.5 \\
\hline 2 & S. S. 30 & $\mathbf{M}$ & I. 60 & $-\infty$ & 72.4 & 4LSB, DM & 24.9 & 12,1 \\
\hline 3 & S. A. 33 & $\mathbf{M}$ & 1.71 & 一 & 58.3 & Innocent SM & 8.0 & 0 \\
\hline 4 & M. S, 21 & $\mathrm{M}$ & 1,72 & - & 48.0 & Pure & 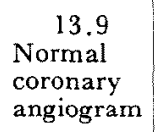 & 5.3 \\
\hline 5 & A. K. 50 & F & 1.30 & - & 54.8 & Pure & - & - \\
\hline 6 & K. E. 52 & $\mathbf{M}$ & 1.62 & - & 50.0 & $\begin{array}{l}\text { Q-1 interval= } \\
0.10 \text { sec } 5 \mathrm{~L} 10 \\
\text { DM, no OS }\end{array}$ & 16.0 & 5.7 \\
\hline 7 & I. S. 28 & $\mathbf{F}$ & 1.38 & - & 50.0 & 2RSB, SM & 9.0 & 4.5 \\
\hline 8 & Y.S. 23 & $\mathrm{~F}$ & 1.40 & 一 & 52.0 & 5LIO, DM, OS & 17.0 & 11.0 \\
\hline 9 & M. K. 39 & $\mathbf{M}$ & 1.62 & - & 67.8 & 5LIO, DM, OS & 44.0 & 11.0 \\
\hline
\end{tabular}


Table I. Continued

\begin{tabular}{|c|c|c|c|c|c|c|c|c|c|c|}
\hline \multirow[b]{2}{*}{$\begin{array}{l}\text { Case } \\
\text { No. }\end{array}$} & \multirow[b]{2}{*}{$\begin{array}{c}\text { Name \& } \\
\text { Age }\end{array}$} & \multirow[b]{2}{*}{ Sex } & \multirow[b]{2}{*}{$\begin{array}{l}\text { Body } \\
\text { Sur- } \\
\text { face } \\
\left(\mathrm{M}^{2}\right)\end{array}$} & \multicolumn{2}{|c|}{ NYHA } & \multicolumn{3}{|c|}{ Lipid Abnormalities } & \multirow[b]{2}{*}{ OGTT } & \multirow[b]{2}{*}{ Comments } \\
\hline & & & & $\begin{array}{l}\text { Func- } \\
\text { tional }\end{array}$ & $\begin{array}{l}\text { Thera- } \\
\text { peutic }\end{array}$ & $\begin{array}{l}\text { Plasma } \\
\text { Chole- } \\
\text { sterol } \\
(\mathrm{mg} / \\
100 \mathrm{ml})\end{array}$ & $\begin{array}{l}\text { Plasma } \\
\text { p-lipo- } \\
\text { protein }\end{array}$ & $\begin{array}{c}\text { Plasma } \\
\text { Triglyce- } \\
\text { ride }\end{array}$ & & \\
\hline 1 & K.O. 55 & $\mathbf{M}$ & 1.56 & $2^{\circ}$ & B & - & 一 & - & Normal & $\begin{array}{l}\text { Onset ; } 6 \text { yrs be- } \\
\text { fore }\end{array}$ \\
\hline 2 & S.S. 30 & $\mathbf{M}$ & 1.60 & $2^{\circ}$ & B & 188 & 407 & - & Normal & $\begin{array}{l}8 \text { y.o.; rheuma- } \\
\text { tic fever }\end{array}$ \\
\hline 3 & S.A. 33 & $\mathbf{M}$ & 1.71 & $1^{\circ}$ & A & 202 & 508 & 146 & Normal & $\begin{array}{l}\text { Arrhythmia, oc- } \\
\text { casionally }\end{array}$ \\
\hline 4 & M.S. 21 & $\mathbf{M}$ & 1.72 & $1^{\circ}$ & A & 134 & 281 & - & Normal & $\begin{array}{l}\text { Since } 17 \text { y.o. } \\
\text { paroxysmal tight- } \\
\text { ness of chest }\end{array}$ \\
\hline 5 & A.K. K. 50 & $\mathbf{F}$ & 1.30 & $1^{\circ}$ & A & 226 & - & - & Normal & $\begin{array}{l}23 \text { y.o.; appen- } \\
\text { dectomy caused } \\
\text { thromboembolism }\end{array}$ \\
\hline 6 & K. E, 52 & $\mathbf{M}$ & 1.62 & $1^{\circ}$ & A & 150 & - & - & Normal & $\begin{array}{l}\text { Onset ; } 5 \text { yrs } \\
\text { before }\end{array}$ \\
\hline 7 & I . S . 28 & $\mathbf{F}$ & 1.38 & $1^{\circ}$ & A & 142 & 457 & 66 & Normal & $\begin{array}{l}\text { Onset ; } 2.5 \text { yrs } \\
\text { before }\end{array}$ \\
\hline 8 & Y.S. 23 & $\mathrm{~F}$ & 1.40 & $2^{\circ}$ & B & - & - & - & Normal & $\begin{array}{l}\text { Onset ; } 12 \text { yrs } \\
\text { before }\end{array}$ \\
\hline 9 & M.K. 39 & $\mathbf{M}$ & 1.62 & $2^{\circ}$ & B & 185 & 357 & 83 & Normal & $\begin{array}{l}\text { Commisurotomy; } \\
1 \text { yr before }\end{array}$ \\
\hline
\end{tabular}

B. Myocardial Ischemic Group

\begin{tabular}{|c|c|c|c|c|c|c|}
\hline \multirow{2}{*}{$\begin{array}{l}\text { Case } \\
\text { No. }\end{array}$} & \multirow{2}{*}{$\begin{array}{c}\text { Name \& } \\
\text { Age }\end{array}$} & \multirow[b]{2}{*}{$\operatorname{Sex}$} & \multirow{2}{*}{$\begin{array}{l}\text { Body } \\
\text { Sur- } \\
\text { face } \\
\left(M^{2}\right)\end{array}$} & \multirow{2}{*}{ Clinical Diagnosis } & \multirow[b]{2}{*}{$\mathrm{BP}$} & ECG Findings \\
\hline & & & & & & At Rest \\
\hline $\mathrm{A}$ & M. Y. 43 & $\mathbf{M}$ & 1.64 & Myocardial infarction & $112 / 60$ & $\begin{array}{l}\text { Abnormal } Q: L_{1}, a V_{L}, R / S V_{1}>1 \text {, } \\
S V_{1}+R V_{5}=35 \mathrm{~mm}\end{array}$ \\
\hline $\mathrm{B}$ & K. A. 46 & $\mathrm{~F}$ & 1.35 & Angina pectoris & $130 / 70$ & $\mathrm{SV}_{\mathrm{t}}+\mathrm{RV}_{5}=28 \mathrm{~mm}$ \\
\hline $\mathrm{C}$ & K. K. 65 & M & 1.62 & Angina pectoris & $140 / 34$ & $\mathrm{SV}_{\mathrm{i}}+\mathrm{RV}_{5}=25 \mathrm{~mm}$ \\
\hline $\mathrm{D}$ & K. M. 47 & M & 1.68 & Myocardial infarction & $120 / 80$ & $V_{1-4}: Q S$ \\
\hline E & K. Y. 59 & M & 1.59 & Angina pectoris & $150 / 70$ & $\begin{array}{l}S V_{1}+R V_{5}=51 \mathrm{~mm} \\
a V_{L}, V_{4,5} S T \text { depression }\end{array}$ \\
\hline
\end{tabular}

The patients were classified either in the myocardial non-ischemic group or in the myocardial ischemic group.

$\mathrm{PA}=$ pulmonary artery; $\mathrm{RV}=$ right ventricle; $\mathrm{NYHA}=\mathrm{New}$ York heart association; OGTT $=$ oral glucose tolerance test; $\mathrm{M}=$ male; $\mathrm{LSB}=$ left sternal border; $\mathrm{DM}=$ diastolic murmur; $\mathrm{F}=$ female; $i \mathrm{RBBB}=$ incomplete right bundle branch block; $\mathrm{OS}=$ opening snap; $\mathrm{SM}=$ systolic murmur; $\mathrm{RVH}=$ right ventricular hypertrophy; $\mathrm{LVH}=$ left ventricular hypertrophy 
Table I. Continued

\begin{tabular}{|c|c|c|c|c|c|c|c|c|c|c|}
\hline & & & Body & $\begin{array}{c}\text { ECG } \\
\text { Findings }\end{array}$ & $\begin{array}{l}\text { Chest } \\
\text { ray } \mathrm{Fi}\end{array}$ & $\begin{array}{c}X-1 \\
\text { ilm }\end{array}$ & Carc & $\begin{array}{l}\text { liac Catl } \\
\text { zation }\end{array}$ & heteri- & \\
\hline $\begin{array}{l}\text { Case } \\
\text { No. }\end{array}$ & $\begin{array}{c}\text { Name \& } \\
\text { Age }\end{array}$ & Sex & $\begin{array}{l}\text { Sur- } \\
\text { face } \\
\left(\mathrm{M}^{2}\right)\end{array}$ & $\begin{array}{c}\text { Masier's } \\
\text { Test }\end{array}$ & $\begin{array}{r}\text { Cardi } \\
\text { thorac } \\
\text { Ratic }\end{array}$ & $\begin{array}{r}\mathrm{PC} \\
\text { Findi }\end{array}$ & 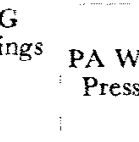 & $\begin{array}{ll}\text { edge } & \mathrm{D} \\
\text { ure } & \mathrm{P} \\
& (\mathrm{n}\end{array}$ & $\begin{array}{l}\text { RV } \\
\text { iastolic } \\
\text { ressure } \\
\mathrm{amHg} \text { ) }\end{array}$ & $\begin{array}{l}\text { Func- } \\
\text { tional }\end{array}$ \\
\hline A & M. Y, 43 & M & 1.64 & - & 53.0 & Pure & 12 & & 4.2 & $2^{\circ}$ \\
\hline B & K. A. 46 & $\mathrm{~F}$ & 1.35 & $\begin{array}{l}\mathrm{V}_{4-6}: \mathrm{ST} \\
\text { depression }\end{array}$ & 52,0 & $\begin{array}{l}\text { Innoc } \\
\text { SM }\end{array}$ & ent & & 5.5 & $3^{\circ}$ \\
\hline C & K. K. 65 & $M$ & 1.62 & $\begin{array}{l}\mathrm{V}_{t-6)}: \mathrm{ST} \\
\text { depression }\end{array}$ & 49.0 & $\begin{array}{l}\text { Innoc } \\
\text { SM }\end{array}$ & cent & & 7.0 & $2^{\circ}$ \\
\hline D & K.M. 47 & M & 1.68 & - & 47.3 & Pure & 19. & & 7.0 & $2^{\circ}$ \\
\hline $\mathrm{E}$ & K.Y. 59 & M & 1.59 & $\begin{array}{l}V_{3,4,5}: S T \\
\text { depression }\end{array}$ & 50,0 & $\begin{array}{l}\text { Innoc } \\
\mathrm{SM}\end{array}$ & ent & 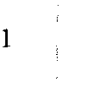 & 8.0 & $2^{\circ}$ \\
\hline & & & & & Lipi & d Abnorma & alitis & & & \\
\hline $\begin{array}{l}\text { Case } \\
\text { No. }\end{array}$ & $\begin{array}{c}\text { Name \& } \\
\text { Age }\end{array}$ & Sex & $\begin{array}{l}\text { Sur- } \\
\text { face } \\
\left(\mathrm{M}^{2}\right)\end{array}$ & $\begin{array}{l}\text { Thera- } \\
\text { peutic }\end{array}$ & $\begin{array}{c}\text { Plasma } \\
\text { Cholesterol } \\
\text { (mg/ } \\
100 \mathrm{ml})\end{array}$ & $\begin{array}{l}\text { Plasma } \\
\beta \text {-lipopro- } \\
\text { tein }\end{array}$ & $\begin{array}{c}\text { Plasma } \\
\begin{array}{c}\text { Triglyce- } \\
\text { ride }\end{array}\end{array}$ & OGTT & Con & ments \\
\hline A & M. Y. 43 & $M$ & 1.64 & $\mathrm{C}$ & 191 & 407 & 54 & Normal & $\begin{array}{l}\text { Onset } \\
\text { before }\end{array}$ & $4 \mathrm{mo}$ \\
\hline B & K.A. 46 & $F$ & 1.35 & $\mathrm{C}$ & 196 & 281 & 58 & Norma & $\begin{array}{l}\text { Onset } \\
8 \text { mo }\end{array}$ & $\begin{array}{l}1 \mathrm{yr} \\
\text { efore }\end{array}$ \\
\hline $\mathrm{C}$ & K. K. 65 & M & 1.62 & C & 196 & 432 & 58 & Normal & $\begin{array}{l}\text { Onset } \\
\text { before }\end{array}$ & 3 yrs \\
\hline D & K.M. 47 & M & 1.68 & $\mathrm{C}$ & 274 & 710 & 177 & Normal & $\begin{array}{l}\text { Onset } \\
\text { before }\end{array}$ & $3 \mathrm{mo}$ \\
\hline E & K. Y, 59 & $M$ & 1.59 & B & 214 & 483 & 122 & Normal & $\begin{array}{l}\text { Onset } \\
\text { before }\end{array}$ & $5-6 \mathrm{yrs}$ \\
\hline
\end{tabular}

were summarized in the myocardial non-ischemic group in Table 11 and in the myocardial ischemic group in Table III. In order to help the understanding, taking the mean and the standard deviation of each variable in Tables II and III, the summary of the effects of Dipyridamole are diagrammatically shown in Fig. 1 and 2.

The great cardiac vein flow (Table II and Fig. 1) increased in all cases in the non-ischemic group after $30 \mathrm{sec}$ of the injection. The peak of the increase of the flow was seen within $2 \mathrm{~min}$ after the injection. The magnitude of the increase of the flow was between 20 to $90 \%$ of the flow before the injection. The duration of the increased flow was more than $10 \mathrm{~min}$. In the 
Table II. The Summary of the Effects of Dipyridamole on the Great Cardic the Coronary Vascular Resistance, the Heart Rate, the Heart Rate

1. Great Cardiac Vein Flow [ml/min ( $4 \%$ from pre-injection value)]:

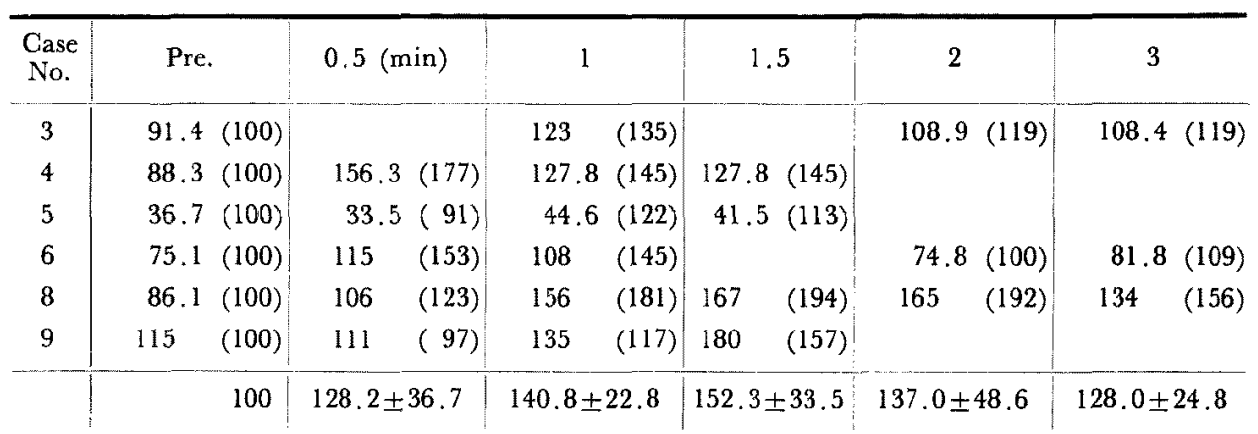

2. Coronary Sinus Ostial Flow $[\mathrm{ml} / \mathrm{min}(\mathcal{\%} \%$ from pre-injection value)]:

\begin{tabular}{l|ll|ll|ll|l|l|l|l|l|l|l}
\hline 1 & 247 & $(100)$ & 380 & $(154)$ & 380 & $(154)$ & 448 & $(181)$ & & & \\
2 & 268 & $(100)$ & 290 & $(108)$ & 315 & $(118)$ & & & 384 & $(143)$ & 306 & $(114)$ \\
3 & $193.8(100)$ & & & 232.9 & $(120)$ & & & 195.1 & $(101)$ & 189 & $(97)$ \\
5 & $328.8(100)$ & & & 339.4 & $(113)$ & 312.3 & $(95)$ & & & & \\
6 & 105 & $(100)$ & 133 & $(127)$ & 135 & $(129)$ & & 100 & $(105)$ & 109 & $(104)$ \\
7 & 111 & $(100)$ & 125 & $(127)$ & 112 & $(101)$ & & 119 & $(107)$ & 126 & $(114)$ \\
\hline & & 100 & $129.0 \pm 18.9$ & $122.5 \pm 18.0$ & $138.0 \pm 60.8$ & $114.0 \pm 19.5$ & $107.3 \pm 8.3$
\end{tabular}

3. Mean Femoral Arterial Pressure [ $\mathrm{mmHg}$ ( $\Delta \%$ from pre-injection value)]:

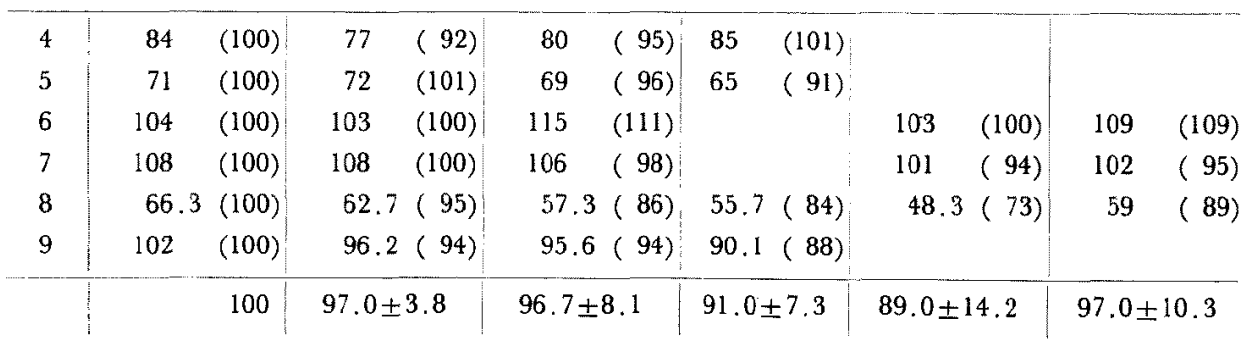

4. Coronary Vascular Resistance $[(3) /(1)$ ( $\Delta \%$ from pre-injection value)]:

\begin{tabular}{l|l|l|l|l|l|l|}
\hline 4 & $0.95(100)$ & $0.49(62)$ & $0.62(65)$ & $0.67(70)$ & & \\
5 & $1.93(100)$ & $2.15(111)$ & $1.55(80)$ & $1.57(81)$ & & \\
6 & $1.38(100)$ & $0.90(65)$ & $1.06(70)$ & & $1.38(100)$ & $1.38(100)$ \\
7 & $0.97(100)$ & $0.86(89)$ & $0.95(98)$ & & $0.85(88)$ & $0.81(84)$ \\
8 & $0.77(100)$ & $0.59(77)$ & $0.37(48)$ & $0.33(43)$ & $0.29(38)$ & $0.44(57)$ \\
9 & $0.89(100)$ & $0.87(98)$ & $0.71(80)$ & $0.50(50)$ & & \\
\hline & 100 & $83.7 \pm 19.2$ & $74.7 \pm 16.8$ & $61.0 \pm 17.6$ & $75.3 \pm 32.9$ & $80.3+21.7$ \\
\hline
\end{tabular}


Vein Flow, the Coronary Sinus Ostial Flow, the Mean Arterial Blood Pressure, and the Blood Pressure Product in the Myocardial Non-ischemic Group

\begin{tabular}{|c|c|c|c|c|c|c|c|}
\hline 4 & 5 & 6 & 7 & 10 & 13 & 16 & 20 \\
\hline $\begin{array}{l}115.3(131) \\
173 \quad(150)\end{array}$ & & $\begin{array}{l}104.3(114) \\
41.5(113) \\
99.6(116)\end{array}$ & & $\begin{array}{ll}94.0 & (125) \\
92.1 & (107)\end{array}$ & $102.5(116)$ & & \\
\hline $140.5 \pm 13.4$ & & $114.3 \pm 1.5$ & & $116.0 \pm 12.7$ & 116 & & \\
\hline
\end{tabular}

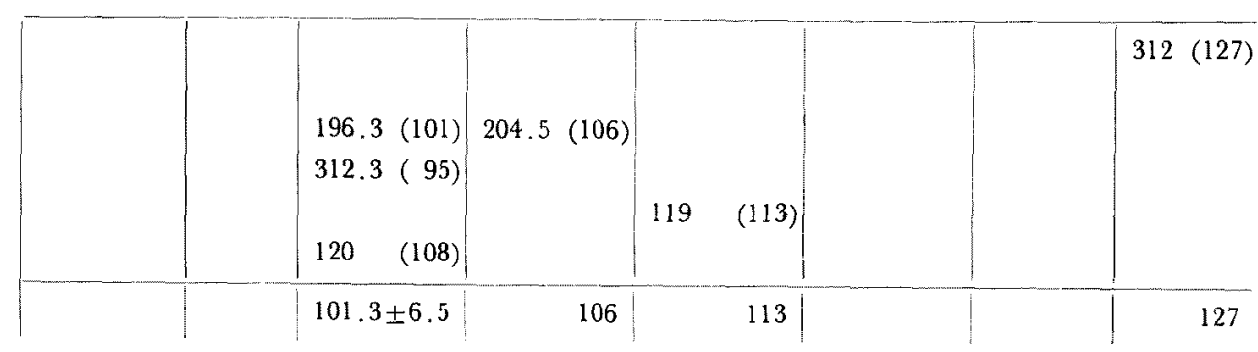

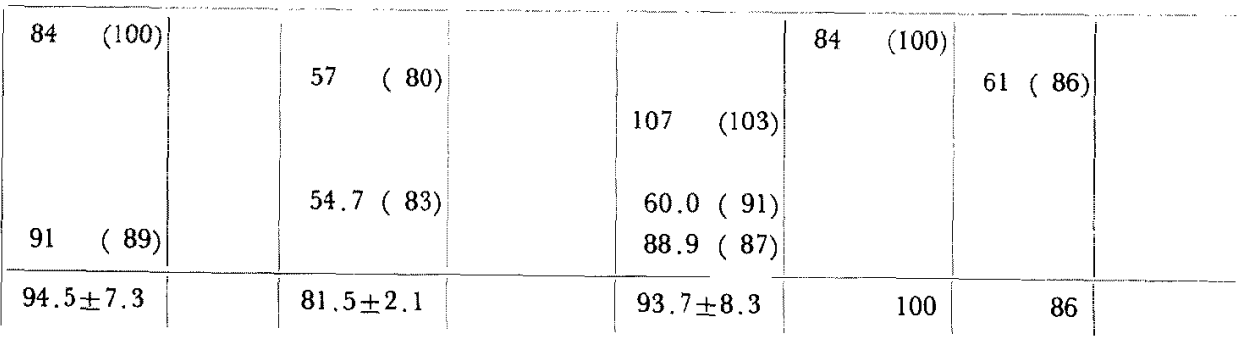

\begin{tabular}{|c|c|c|c|}
\hline $\begin{array}{l}0.73(77) \\
0.53(60)\end{array}$ & $\begin{array}{l}1.26(65) \\
0.55(71)\end{array}$ & $\begin{array}{l}1.14(83) \\
0.65(84)\end{array}$ & $0.82(86)$ \\
\hline $68.5 \pm 12.0$ & $68.0 \pm 4.2$ & $83.5 \pm 0.7$ & 86 \\
\hline
\end{tabular}


Table II. Continued

5. Heart Rate $[/ \min (\Delta \%$ from pre-injection value)]:

\begin{tabular}{|c|c|c|c|c|c|c|c|c|c|c|c|c|}
\hline $\begin{array}{c}\text { Case } \\
\text { No. }\end{array}$ & \multicolumn{2}{|c|}{ Pre. } & \multicolumn{2}{|c|}{$0.5(\mathrm{~min})$} & \multicolumn{2}{|c|}{1} & \multicolumn{2}{|c|}{1.5} & \multicolumn{2}{|c|}{2} & \multicolumn{2}{|c|}{3} \\
\hline 1 & 50 & $(100)$ & 60 & $(100)$ & 60 & $(100)$ & 63 & $(105)$ & & & & \\
\hline 2 & 80 & $(100)$ & 79 & ( 98$)$ & 85 & (106) & 84 & (105) & 83 & $(104)$ & 80 & $(100)$ \\
\hline 3 & 72 & $(100)$ & & & 90 & (125) & & & 81 & (113) & 83 & (117) \\
\hline 4 & 57 & $(100)$ & 60 & (105) & 60 & (105) & 60 & (105) & & & & \\
\hline 5 & 68 & $(100)$ & 68 & $(100)$ & 68 & $(100)$ & 72 & $(106)$ & & & & \\
\hline 6 & 104 & $(100)$ & 103 & $(100)$ & 115 & (111) & & & 103 & $(100)$ & 113 & (109) \\
\hline 7 & 120 & $(100)$ & 126 & (105) & 126 & (105) & 126 & $(105)$ & 126 & $(105)$ & 132 & (110) \\
\hline 8 & 63 & $(100)$ & 63 & $(100)$ & 65 & (103) & 66 & $(105)$ & 66 & $(105)$ & 66 & (105) \\
\hline \multirow[t]{2}{*}{9} & 81 & $(100)$ & 81 & $(100)$ & 87 & (107) & 90 & $(111)$ & & & & \\
\hline & & 100 & 101.0 & 2.6 & 106.9 & 7.6 & 106 & \pm 2.2 & 105. & 4.7 & 108. & 6.3 \\
\hline
\end{tabular}

6. Heart Rate $\times$ Mean Femoral Arterial Pressure (beats $\times \mathrm{mmHg} / \mathrm{min}$ ) :

\begin{tabular}{l|rr|rr|rrr|r|r|r|r|r|} 
& 4788 & $(100)$ & 4620 & $(96)$ & 4800 & $(100)$ & 5100 & $(107)$ & & & & \\
5 & 4828 & $(100)$ & 4896 & $(101)$ & 4692 & $(97)$ & 4680 & $(97)$ & & & & \\
6 & 5304 & $(100)$ & 5562 & $(105)$ & 6210 & $(117)$ & & & 5253 & $(99)$ & 5886 & $(111)$ \\
7 & 12960 & $(100)$ & 13608 & $(105)$ & 13356 & $(103)$ & & & 12726 & $(98)$ & 13464 & $(104)$ \\
8 & $4126.9(100)$ & 3950.1 & $(95)$ & 3724.5 & $(89)$ & 3676.2 & $(88)$ & $3187.8(76)$ & $3894.0(93)$ \\
9 & 8262 & $(100)$ & 7792.2 & $(94)$ & 8317.2 & $(101)$ & 8109.0 & $(98)$ & & & & \\
\hline & & 100 & $99.3 \pm 5.0$ & $101.2 \pm 9.2$ & $97.5 \pm 7.8$ & $91.0 \pm 7.8$ & $102.7 \pm 9.0$
\end{tabular}

myocardial ischemic group the increase of the flow was seen in some cases in this group similar to the control group. Namely, the peak of the increase of the flow was also seen within 2 min after the injection. The magnitude of the increase of the flow was less than the control group and it was in 20 to $50 \%$ compared to the flow before the injection. The duration of the increase of the flow was longer than $6 \mathrm{~min}$. In the myocardial ischemic group, however, some cases did not show any increase of the flow in contrast to the cases so far described.

The coronary sinus ostial flow (Table II and Fig. 1) increased also in all cases in the myocardial non-ischemic group after Dipyridamole similar to the response to the great cardiac vein flow. The peak and the duration of the increase of the flow were also similar to the increase in the great cardiac vein flow. In 1 case (case 1 ) the duration of the increased flow was definitely seen even in the 20 min after the injection. In the myocardial ischemic group (Table III and Fig. 2), the pattern of the increase of the flow was almost similar to the myocardial non-ischemic group. Therefore, the increase of either the great cardiac vein or the coronary sinus ostial flow was definitely 


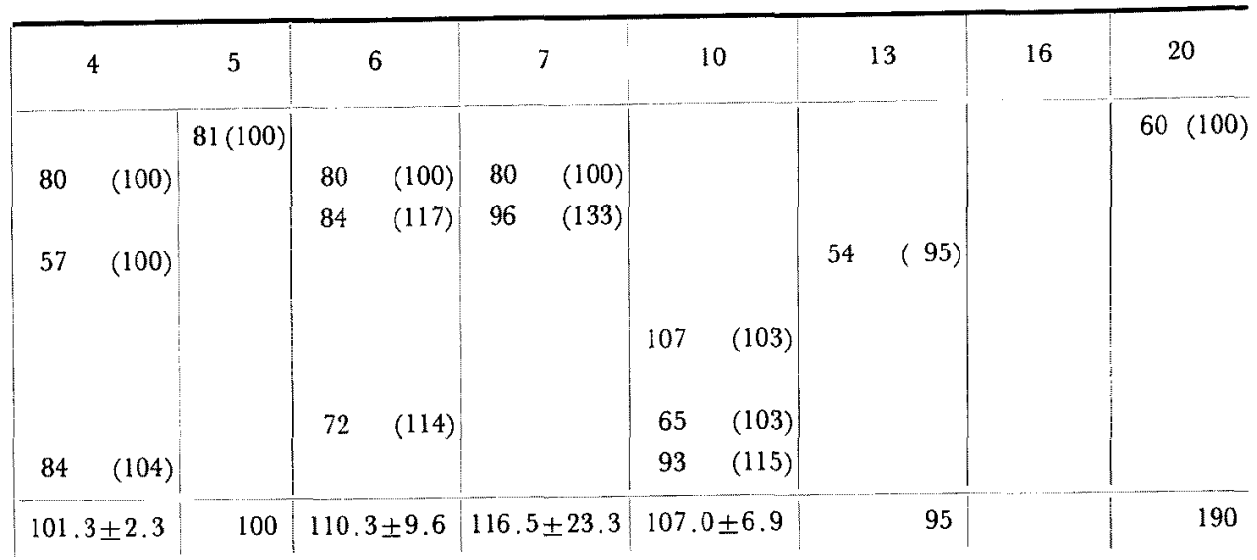

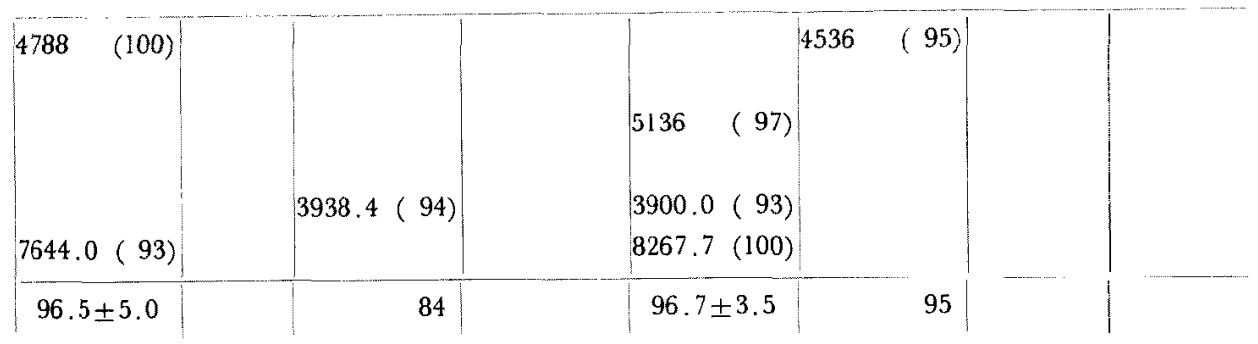

seen in most cases with some exceptions.

The mean femoral arterial pressure (Table II and Fig. 1) in the myocardial non-ischemic group decreased slightly in 5 cases out of 6 . The peak of the decrease in the blood pressure was in $2 \mathrm{~min}$, coinciding to the increase of the flow in this same period. In some cases the decrease of the flow was delayed until $6 \mathrm{~min}$, even though the increase of the coronary blood flow was seen in this time. The magnitude of the decrease in the blood pressure was less than 20\%. In the myocardial ischemic group (Table III and Fig. 2), the changes of the blood pressure after the injection was less than those of the changes in the myocardial non-ischemic group. Namely, the changes of the blood pressure were almost unrecognizable in the myocardial ischemic group.

The data so far disclosed indicate, in the myocardial non-ischemic group, the increase of the coronary flow and the decrease of the pressure. Therefore, the calculated coronary vascular resistance decreased definitely. The decrease of the coronary vascular resistance was more remarkably seen in the myocardial non-ischemic group than the myocardial ischemic group as shown in the Table II and Fig. 1. Namely, the coronary vascular resistance was 


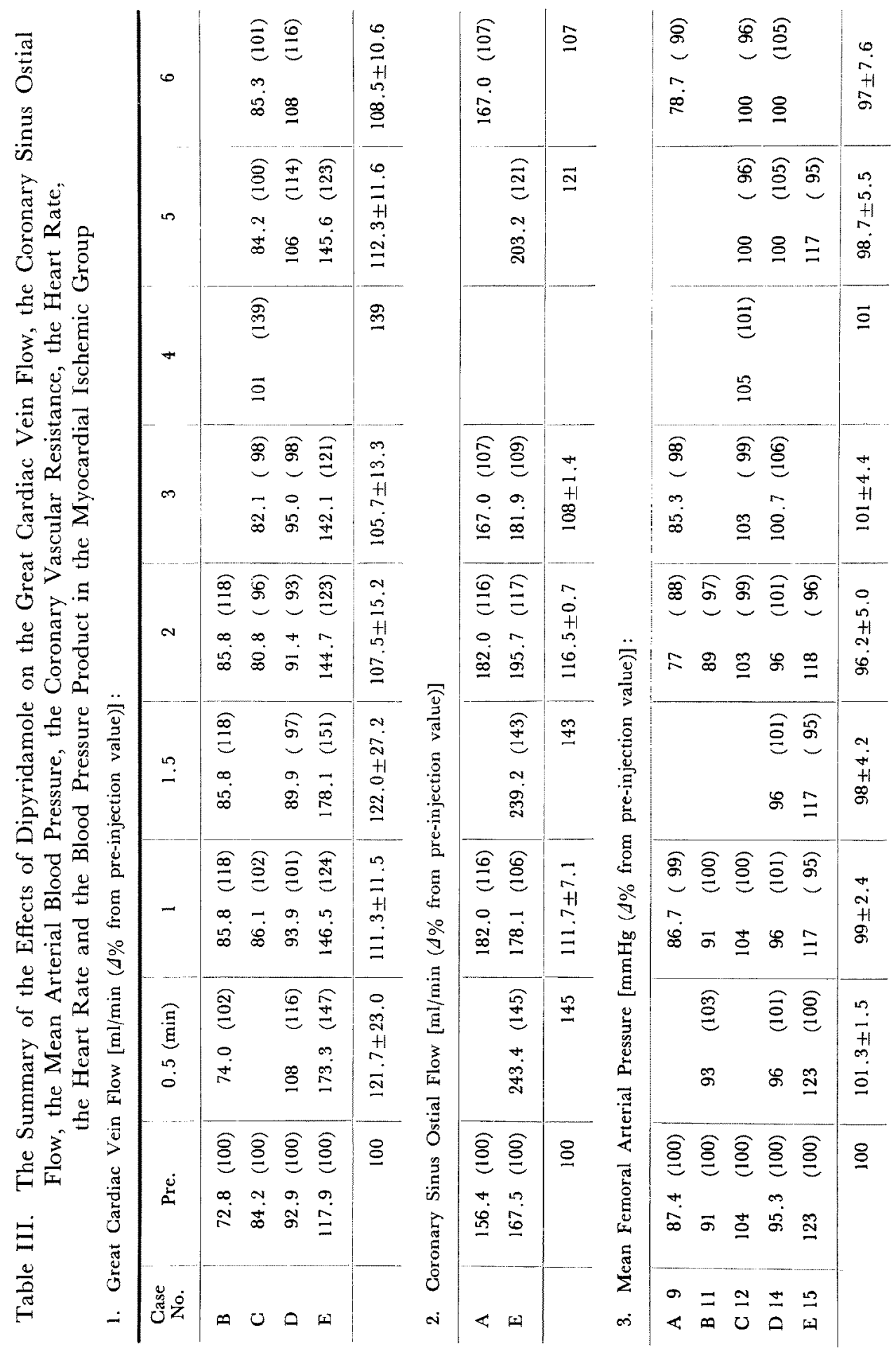




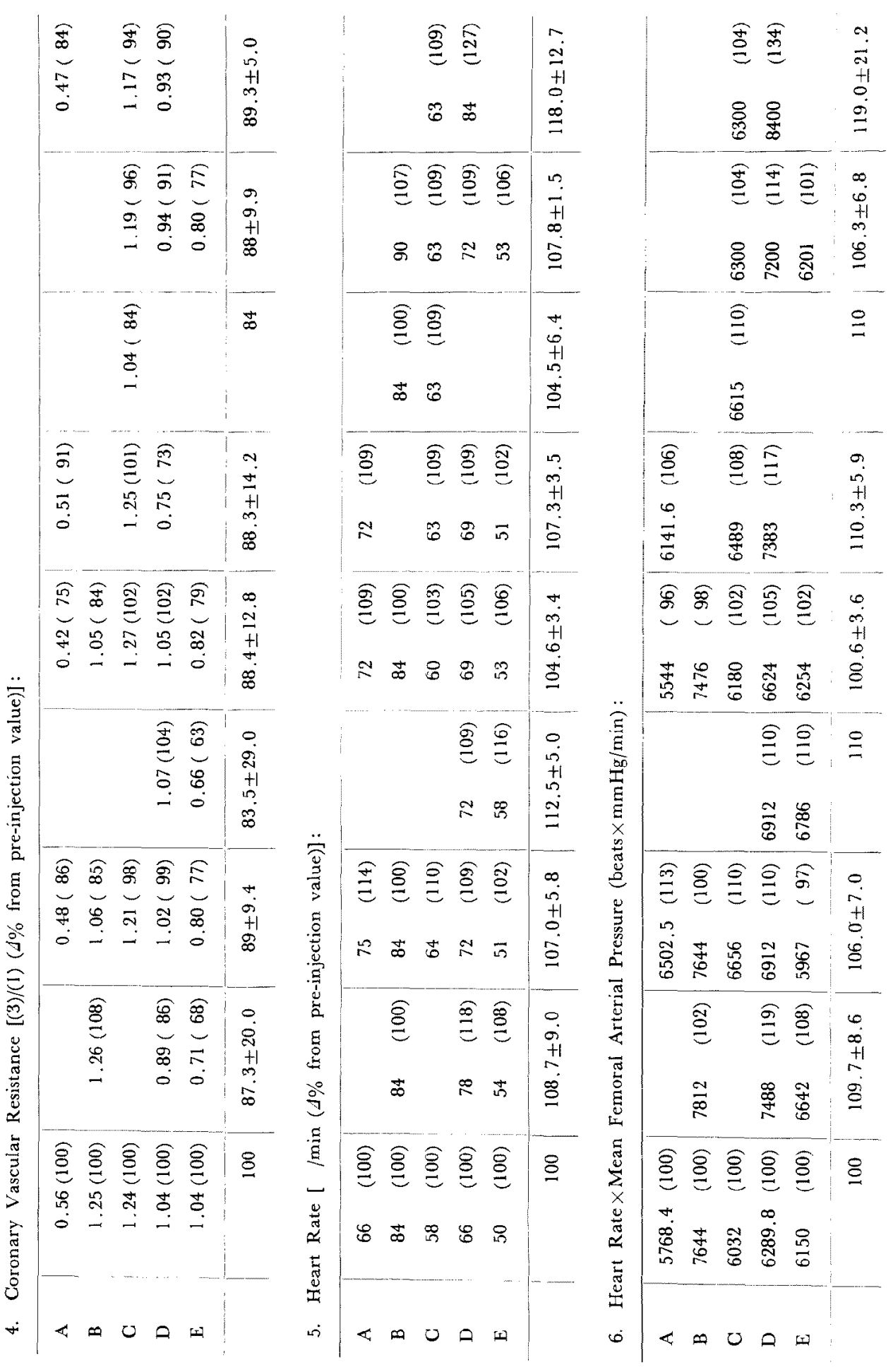



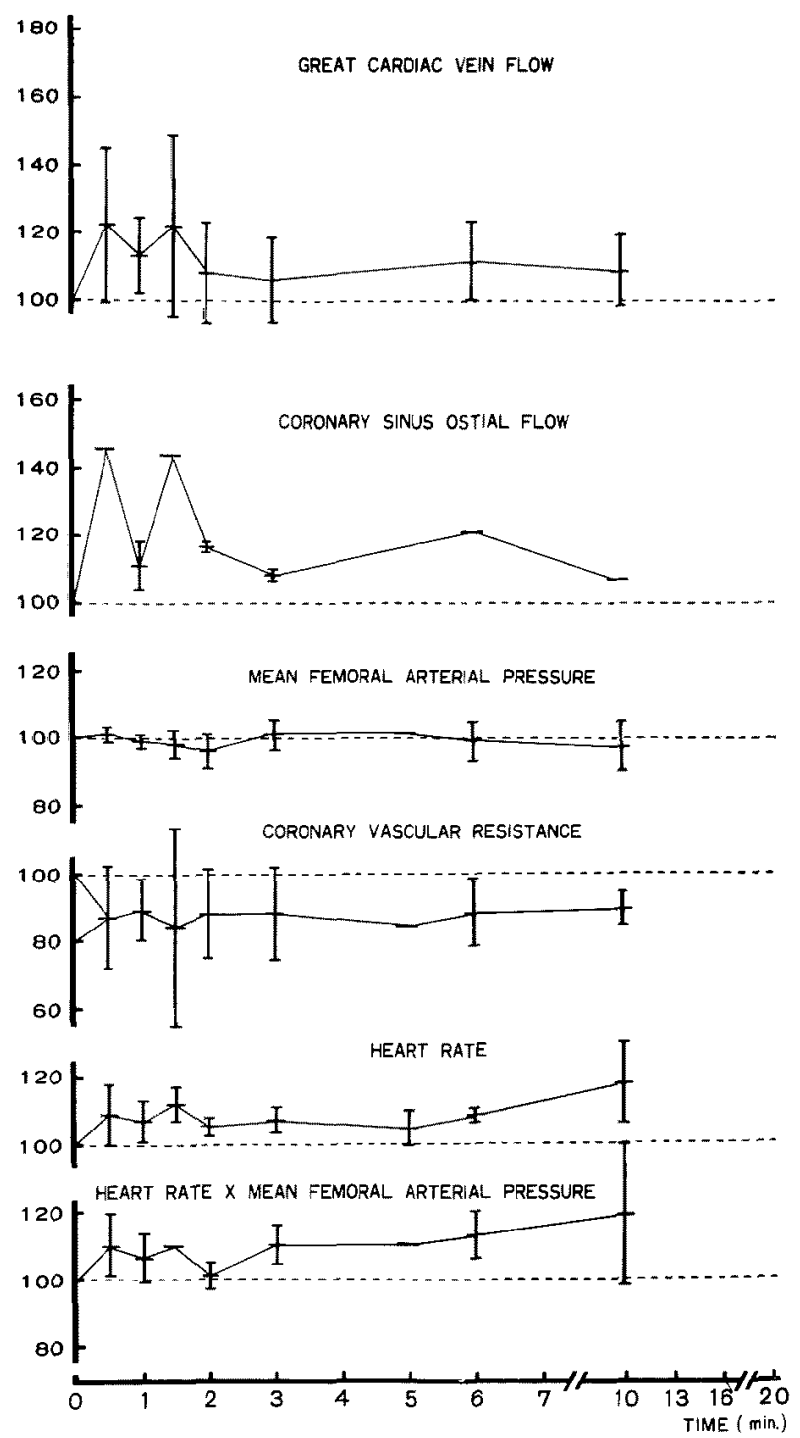

Fig. 1. The summary of the effect of Dipyridamole on the coronary hemodynamics in the myocardial non-ischemic group. The changes were shown in percentage from the value before the injection. The mean and the one standard deviation is shown as the middle bar with the short arms.

definitely decreased even in the myocardial ischemic group (Table III and Fig. 2). The duration of the decrease in the resistance was more than 10 to $13 \mathrm{~min}$.

The heart rate in the myocardial non-ischemic group increased definitely in about $10 \%$ in all cases. The increase in the heart rate during this period coincided almost to the increase of the coronary blood flow. This increase 

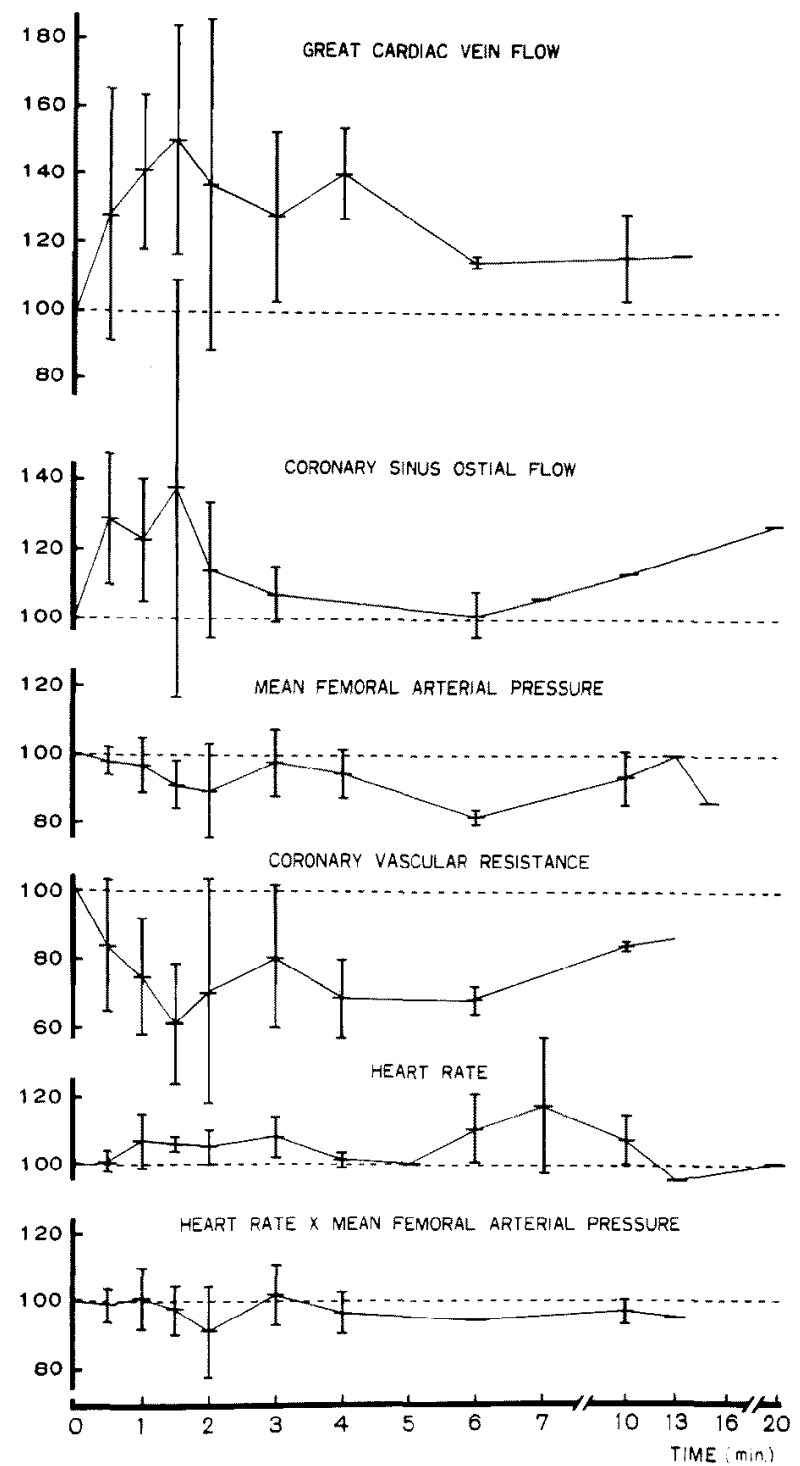

Fig. 2. The summary of the effect of Dipyridamole on the coronary hemodynamics in the myocardial ischemic group. The changes were shown in percentage from the value beforc the injection of Dipyridamole. The middle bar indicates the mean value and one standard deviation is also indicated as the short bar.

in the heart rate was also seen in the myocardial group.

The rate and the pressure product did not change significantly in the myocardial non-ischemic group because the mean femoral arterial pressure decreased and the heart rate increased slightly. In the myocardial non- 
ischemic group, the mean femoral arterial pressure did not change and the heart rate increased slightly. Therefore, the rate and pressure product increased rather slightly in this group.

\section{Discussion}

The experimental pharmacological effect of Dipyridamole in the animals has been reported as follows: (1) Dipyridamole increases the myocardial blood flow. ${ }^{2}$ Therefore, it boost the development of the formation of the collateral channels in the myocardial ischemic area. ${ }^{13)}$ (2) It improves the myocardial metabolism by the better utilization of the myocardial oxygen. (3) It shows the positive inotropic effect resulting in the improvement in the myocardial contractility. ${ }^{6}$ )

The evaluation of these effects of Dipyridamole directly in man is quite difficult in the clinical medicine. However, we developed the new method for the measurement of the coronary blood flow continuously in man by the continuous local thermodilution method. ${ }^{12}$ ) This new method enabled us to measure the effect of Dipyridamole especially on the coronary blood flow in man. This project has not been completed as a whole, because the effect of Dipyridamole in animals disclosed the above mentioned 3 items, and these items should be clarified in man. The data so far completed disclosed the effect of the item (1) which was described in the animal experiment.

Because there was no method of the continuous measurement of the coronary blood flow in man, there has been reported no direct proof that Dipyridamole increases the coronary blood flow in man continuously. This is the first report of the continuous measurement of the coronary blood flow in man. Even by the nitrous oxide method, practically the flow was able to be measured in every $10 \mathrm{~min}$. Wendt and $\mathrm{Bing}^{6 /}$ showed the increase of the coronary blood flow by the nitrous oxide method. The 8 cases out of 9 showed the increase of the flow of $18 \%$ in average. The coronary vascular resistance, therefore, decreased. The rest of the reports proved the increase of the coronary blood flow indirectly by measuring the oxygen content in the coronary sinus. Kinsella and McGregor ${ }^{3)}$ reported the increase of the coronary blood flow even in the presence of the severe coronary heart disease. They gave $20 \mathrm{mg}$ of Dipyridamole intravenously and measured the oxygen in the coronary sinus in 2, 5, 10, and $30 \mathrm{~min}$. Bernsmeier ${ }^{4)}$ measured also oxygen in the coronary sinus and showed the increase of about $10 \%$ by Dipyridamole of $0.2 \mathrm{mg} / \mathrm{Kg}$ given intravenously. The effect disappeared in $15 \mathrm{~min}$. Therefore, he doubted the effectiveness of Dipyridamole. Peel ${ }^{51}$ injected Dipyridamole $(0.16$ to $0.30 \mathrm{mg} / \mathrm{Kg})$ intravenously in the patients of mitral stenosis. The 
oxygen in the coronary sinus increased from 7 to $36 \%$. Knipping ${ }^{8}$ gave $20 \mathrm{mg}$ of Dipyridamole in 20 patients and showed the increase of the oxygen in the coronary sinus in $5 \mathrm{~min}$. Schollmeyer ${ }^{81}$ measured also the oxygen in the coronary sinus in the myocardial non-ischemic patient after injection of Dipyridamole $(0.4$ to $0.8 \mathrm{mg} / \mathrm{Kg}$ in $2 \mathrm{~min}$ ). The oxygen in the coronary sinus increased in $3 \mathrm{~min}$ and the increase continued for more than $60 \mathrm{~min}$. He also noted the increase of the frequency of the heart rate. The blood pressure changes were not noted. Hilgar' ${ }^{91}$ also showed the similar results. Doll10) clarified the increase of the arteriovenous oxygen difference after Dipyridamole. Rudolph ${ }^{11}$ showed the transient increase in the coronary blood flow of about $10 \%$ after Dipyridamole $(0.2$ to $0.4 \mathrm{mg} / \mathrm{Kg})$. Therefore, he concluded that Dipyridamole is not effective in acute disturbances of the coronary circulation.

In this study, the continuous measurement of the coronary blood flow in man showed that the coronary blood flow increased definitely in the myocardial non-ischemic group. In the myocardial ischemic group, some patients showed the increase of the flow and some other patients showed no increase of the flow. According to the clinical manifestations and the laboratory findings, these differences in the response to the drug would be based upon the pathologic changes of the coronary arteries and the existence of the myocardial ischemia. The increase of the coronary blood flow was quite similar to the reports such as described already. However, the magnitude, the time of peak and the duration of the increased flow were well disclosed by this study.

It is therefore quite possible that Dipyridamole increases the coronary blood flow in most of the myocardial ischemic patients and improves the myocardial efficiency. ${ }^{13)}$ However, the increase of the coronary blood flow does not mean the improvement of the myocardial ischemia, because the increased flow might be shunted away from the ischemic area. The attempt to assess the long-term effects attributable to Dipyridamole has been reported by Mason et al.13) Their data showed that Dipyridamole can favorably influence the development of intercoronary anastomosis when administered over the long term. The other question which should be answered is that in some patients of myocardial ischemia there was no increase of the coronary blood flow and so how is Dipyridamole effective to such a patient. The study such as Mason et $\mathrm{al}^{13)}$ might answer to this question in future. We also have attempted to measure the myocardial metabolic changes such as the reversal of the lactate production by the anaerobic metabolism in the myocardium. Therefore, it is quite possible that Dipyridamole, acting as the coronary vasodilator, increases the coronary flow and might boost the formation of the collateral channels in most of the patients even with moderate myocardial ischemia. However, some patients with diffuse myocardial ischemic changes did not show 
the increase of the coronary blood flow. The effectiveness of Dipyridamole even to such patients will require further study by certifying the improvement of the myocardial ischemic metabolism directly in man.

\section{REFERENCES}

1. Fam WM, McGregor M: Effect of coronary vasodilator drugs on retrograde flow in areas of chronic myocardial ischemia. Circulat Res 15: 355, 1964

2. Bretschneider HJ ct al: Effect of a Pyrimidopyrimidine derivative on oxygen supply to the myocardium. Arzineim-Forsch 9: 49, 1959

3. Kinsella D et al: Studies with a new coronary vasodilator drug: Persantin. Am Heart J 63 : 146,1962

4. Rudolph W et al: Die Wirkung von 2, 6-Bis (diäthanolamino)-r, 8-diperidino-pyrimido (5, 4d) pyrimidin (Persantin) auf die Koronardurchblutung, die Sauerstoffextraktion und die Subtratextraktion des menschlichen Herzens. Klin Wschr 42: 667, 1964

5. Peel AAF et al: Observations on the coronary vasodilator effect of 'Persantin'. Scot med J 6: 403, 1961

6. Wendt VE et al: The relationship between coronary blood flow, myocardial oxygen consumption and cardiac work as influenced by Persantin. Am J Cardiol 9: 449, 1962

7. Knipping HW et al: Clinical and experimental research with a new pyrimido-pyrimidine derivative. Arzneim-Forsch 10:364, 1960

8. Schollmeyer PJ et al: Sauerstoffversorgung, Sauerstoffextraktion und Substrate-extraktion des menschlichen Herzens unter dem Einfluss von 2,6-Bis (diäthanolamino)-4,8-dipiperidinopyrimido (5,4-d) pyrimidin (Persantin). Klin Weschr 47: 42, 1969

9. Hilger $\mathrm{H}$ et al: Änderung der Koronarenarterio-venesen- $\mathrm{O}_{2}-$ Differenz beim Menschen nach intravenöser Injektionen von Dipyridamole (Persantín). Kreislauf Forcch 56: 1192, 1967

10. Doll E et al: Sauerstoffdruck und Sauerstoffsättigung in koronarvenösen Blut sowie die Veränderungen der arterio-koronarvenösen $\mathrm{O}_{2}$ Gehalt Differenz und des Koronardurchflusses unter hohen Dosen von 2,6 (diäthanolamino) 4,8-dipiperidino-pyrimido 5,4-d pyrimidin (Persantin). Kreislauf Forsch 55: 10751966

11. Peel AAF ct al: The coronary vasodilator effect of Persantin. Verh Dtsch Kreislauf Forsch 27: 314,1961

12. Ganz W, Tamura $\mathrm{K}$ et al: Measurement of coronary sinus blood flow by continuous thermodilution in man. Circulation $44: 181,1971$

13. Vineberg $\mathrm{AM}$ et al: The effect of Persantin on intercoronary collateral circulation and survival during gradual experimental coronary occlusion. A preliminary report. Canad Med Ass J 87: 336, 1962

14. Mason RLN et al: A study of the effects of dipyridamole on the coronary circulation in man. (not published) 